Т.В. Дегтярева*, А.А. Лиховид, Н.Г. Лиховид

Материалы и методы:

Результаты исследования:

Обсуждение и заключения:

Ключевые слова:
Северо-Кавказский федеральный университет, г. Ставрополь, Россия. *dtb.70@mail.ru

\section{ГЕОХИМИЧЕСКАЯ ДИФФЕРЕНЦИАЦИЯ ЛИТОГЕННОЙ ОСНОВЫ ЛАНДШАФТОВ БОЛЬШОГО КАВКАЗА}

актуальность исследования обусловлена необходимостью выявления роли литогенной основы ландшафтов Большого Кавказа в формировании их геохимических особенностей и закономерностей миграции и концентрации химических элементов в различных ландшафтно-геохимических условиях. Цель статьи заключается в изучении специфики геохимической дифференциации приповерхностных (почвообразующих) отложений ландшафтов Большого Кавказа.

использован метод сравнения химического состава основных почвообразующих комплексов физико-географических подобластей северных склонов Большого Кавказа с региональным литогеохимическим фоном.

Выявлена геохимическая дифференциация почвообразующих комплексов пород для физико-географических подобластей северных склонов Большого Кавказа, выделяемых при физико-географическом районировании территории. Области распространения отдельных комплексов почвообразующих пород рассматриваются как литогеохимические поля региональных геосистем. На основании расчета коэффициентов региональной концентрации для литогеохимических полей проведено выделение выше- и нижефоновых ассоциаций химических элементов относительно регионального литогеохимического фона, за который принято среднее содержание химических элементов в почвообразующих комплексах Северного Кавказа

авторами сделан вывод, что на формирование геохимических особенностей поверхностных почвообразующих комплексов отложений ландшафтов северных склонов Большого Кавказа определенное влияние оказали длительные процессы выветривания в течении орогенного этапа развития региона в позднем кайнозое. Выше- и нижефоновые ассоциации химических элементов в почвообразующих комплексах, рассчитанные относительно регионального литогеохимического фона Северного Кавказа, в какой-то мере отражают степень геохимической подвижности химических элементов, эволюционно сложившейся в литогенной основе ландшафртов Большого Кавказа. Практическая значимость полученных результатов заключается в определении базовой информации по литогенной основе ландшафтов Большого Кавказа, необходимой для обоснованного геоэкологического мониторинга.

Большой Кавказ, литогенная основа, почвообразующие породы, литогеохимические поля, ассоциации химических элементов. 
Degtyarova T.V.*, North-Caucasian Federal University, Likhovid A.A., $\quad$ Stavropol, Russia.

Likhovid N.G._ $\quad{ }^{*} \mathrm{dtb} .70 @ m a i l . r u$

\section{GEOCHEMICAL DIFFERENTIATION OF THE LITHOGENIC BASE OF THE LANDSCAPES OF THE GREATER CAUCASUS}

Introduction:

the relevance of the study is due to the need to identify the role of the lithogenous basis of the landscapes of the Greater Caucasus in the formation of their geochemical features and patterns of migration and concentration of chemical elements in various landscape and geochemical conditions. The purpose of the article is to study the specific geochemical differentiation of near-surface (soil-forming) sediments of the landscapes of the Greater Caucasus.

Materials and methods: a method was used to compare the chemical composition of the main soil-forming complexes of the physico-geographical subregions of the northern slopes of the Greater Caucasus with a regional lithogeochemical background.

Results:

Geochemical differentiation of soil-forming rock complexes was revealed for the physico-geographical subregions of the northern slopes of the Greater Caucasus, which are allocated in the physico-geographical zoning of the territory. Areas of distribution of individual complexes of soil-forming rocks are considered as lithogeochemical fields of regional geosystems. Based on the calculation of regional concentration coefficients for lithogeochemical fields, the above and below-background associations of chemical elements were distinguished relative to the regional lithogeochemical background, for which the average content of chemical elements in the soil-forming complexes of the North Caucasus was adopted.

Discussion and conclusion:

the authors concluded that the formation of geochemical features of surface soilforming complexes of sediments in the landscapes of the northern slopes of the Greater Caucasus was greatly influenced by long-term weathering processes during the orogenic stage of the region's development in the Late Cenozoic. The practical significance of the results obtained is to determine the basic information on the lithogenic basis of the landscapes of the Greater Caucasus, which is necessary for sound geoecological monitoring.

Key words: $\quad$ Greater Caucasus, lithogenic base, soil-forming rocks, lithogeochemical fields, associations of chemical elements.

For citation: Degtyareva T.V., Likhovid A.A. Geochemical differentiation of the lithogenic base of the landscapes of the Greater Caucasus // Integration of education. 2018. DOl:

\section{Введение}

Одним из наиболее значимых факторов эволюции геохимии ландшафтов Большого Кавказа является литогенный фактор. Литогенная основа ландшафтов по сравнению с прочими компонентами среды отличается относительной стабильностью, определяющей устойчивый характер 
геосистем. Как отмечает Ф.Н. Мильков [1], в широком смысле под литогенной основой ландшафтов понимается весь комплекс геолого-геоморфологических особенностей территории, включающий стратиграфию и литологию горных пород, древнюю и новейшую тектонику, современные тектонические движения, рельеф поверхности. Частью литогенной основы ландшафта является сравнительно маломощный поверхностный слой горных пород, в котором осуществляется обмен веществом и энергией с поверхностью, биотой и атмосферой. Такие поверхностные слои горных пород, подвергаясь процессам гипергенеза (выветривания) и переотложения, представляют верхнюю часть коры выветривания, т.е. «...самую наружную часть земной коры, которая преобразована (или преобразуется) под непосредственным влиянием ландшафтно-геохимических условий» [2, с. 229].

Становление геохимических особенностей литогенной основы ландшафтов Большого Кавказа происходило в контексте геологической истории и воздействия процессов гипергенеза в постоянно менявшихся ландшафтногеохимических условиях. В настоящее время для региона характерны большие различия в генезисе, литологии и геохимии коренных пород. В силу высокой степени обнаженности коренных пород и низкой мощности покровных рыхлых образований для большей части территории Большого Кавказа В.В. Дьяченко $[3,4]$ рассматривает коренные горные породы как почвообразующие. При этом их геохимическая специфика и дифференциация по генезису, возрасту, гранулометрическому и минеральному составам, ассоциациям химических элементов оказывала непосредственное влияние на образование четвертичных отложений и процессы почвообразования [5].

Целью исследования было изучение геохимической дифференциации почвообразующих комплексов крупных геосистем Большого Кавказа относительно регионального литогеохимического фона. Геохимические особенности отложений рассматриваются в аспекте гипергенных преобразований, происходивших в горных породах и слагающих их минералах при выходе пород на поверхность, и миграции подвижных соединений химических элементов по элементам рельефа. Как отмечает В.В. Добровольский, «выветривание (гипергенез) представляет собой единый процесс перераспределения химических элементов применительно к ландшафтно-геохимическим условиям» [2, c. 230].

\section{Материалы и методы исследований}

Геохимическая дифференциация литогенной основы изучена для физико-географических подобластей северных склонов Большого Кавказа, выделение которых проведено В.А. Шальневым в границах физико-географических областей при физико-географическом районировании Северного Кавказа [6]. На северном склоне Большого Кавказа выделены высокогорная и среднегорно-низкогорная физико-географические области. Высо- 
когорная область включает Эльбрус-Казбековскую высокогорную подобласть альпийского рельефа на доюрских складчато-глыбовых структурах и Североюрско-Дагестанскую высокогорно-среднегорную подобласть на раннеальпийских складчато-глыбовых структурах. Среднегорно-низкогорная область также в своем составе содержит две подобласти: Кубано-Дагестанскую среднегорную на позднеальпийских складчатых и моноклинальных структурах и Кубано-Терско-Сунженскую низкогорную на новейших складчатых структурах и предгорных равнин.

Физико-географические подобласти соответствуют крупным геотектоническим и геологическим структурам изучаемого региона с определенными структурно-формационными комплексами горных пород. Области распространения комплексов почвообразующих пород рассматриваются как литогеохимические поля данных региональных геосистем, отличающиеся относительной однородностью в распределении химических элементов. Характеристика литогеохимических полей микроэлементов проводится путем сравнения уровней содержания элементов с региональными фоновыми показателями. За региональный литогеохимический фон принято среднее содержание химических элементов в почвообразующих комплексах Северного Кавказа, рассчитанное на основании данных В.В. Дьяченко [3, 4]. Вариабельность литогеохимического фона в пределах литогеохимических полей выявляется с помощью коэффициентов региональной концентрации (Крк), представляющих отношение содержания химического элемента в почвообразующем комплексе пород к региональному литогеохимическому фону. Вышефоновые содержания (значения Крк >1,0) свидетельствуют об относительном обогащении химическим элементом литогеохимического поля, нижефоновые содержания (Крк<1,0) - об его обеднении, выносе химического элемента.

\section{Результаты исследований и их обсуждение}

В орогенный этап развития Большого Кавказа, в связи с общим формированием горного сооружения, геологические структуры физикогеографических подобластей испытывали поднятие и последовательно освобождались от моря [7]. Слагающие их коренные породы выходили на поверхность и подвергались процессам выветривания разной продолжительности, характера и интенсивности в зависимости от меняющихся ландшафтно-геохимических условий. Воздействие процессов выветривания приводило к специфичным для каждого комплекса пород изменениям их минералогического и химического состава, появлению в них соединений химических элементов различной геохимической подвижности. «В процессе гипергенеза происходит своеобразная сортировка минералов исходных пород, обусловленная разрушением гипергенно неустойчивых минералов и относительной концентрацией устойчивых минералов» [2, с. 21]. 
В течение позднего кайнозоя создавались различные геохимические обстановки, по-разному влияющие на устойчивость минеральных соединений поверхностных комплексов пород и вовлечение в миграцию химических элементов из пород. Косвенным результатом гипергенного перераспределения химических элементов стали вышефоновые и нижефоновые ассоциации элементов в почвообразующих комплексах пород. В ходе длительного гипергенного преобразования исходных пород неустойчивые минералы разрушались и подвижные формы химических элементов постепенно выносились из толщи выветривающихся пород. В настоящее время такие химические элементы, входившие в состав неустойчивых к выветриванию минералов, отличаются нижефоновым содержанием в породах. Химические элементы с вышефоновым содержанием могут рассматриваться как элементы, находившиеся в прочносвязанных и устойчивых к длительному выветриванию первичных минералах, и, в силу этого, слабо выносившиеся из пород. К концентрированию определенных химических элементов в отложениях приводило также возникновение особых устойчивых минералов, порожденных конкретными ландшафтно-геохимическими условиями, - минеральных гипергенных новообразований [8-11]. Локальные аномальные вышефоновые концентрации химических элементов в пределах литогеохимических полей формировались и в связи с месторождениями рудных элементов и их ореолами рассеяния.

Процессы выветривания приповерхностных (почвообразующих) отложений неразрывно сопровождались денудацией, т.е. перемещением продуктов выветривания. Латеральное перемещение химических элементов и их вторичная концентрация в приповерхностных комплексах пород во многом определялись рельефом, который воздействовал на перераспределение воды, подвижных форм химических элементов и окислительно-восстановительные условия. В этом аспекте существенна принадлежность почвообразующих комплексов к автоморфным и гидроморфным семействам кор выветривания, их остаточным и переотложенным формам $[8,12-16]$.

Рассмотрим геохимическую дифференциацию почвообразующих комплексов пород физико-географических подобластей северных склонов Большого Кавказа и ассоциации химических элементов с выше- и нижефоновыми значениями относительно регионального литогеохимического фона.

Эльбрус-Казбековская высокогорная физико-географическая подобласть северного склона Большого Кавказа включает современные высокогорные ландшафты, образованные на метаморфических и магматических породах. Преобладание в рельефе высоких эрозионно-тектонических гор позволяет рассматривать поверхностные слои горных пород высокогорной подобласти как элементы автоморфной коры выветривания остаточной и переотложенной форм. В пределах морфоструктурных комплексов Главного Кавказского и Бокового хребтов выделяются региональные 
литогеохимические поля протерозойских кристаллических сланцев и гнейсов и палеозойских гранитоидов. В пределах Передового хребта развиты литогеохимические поля палеозойских вулканогенно-терригенных и терригенных отложений, а также протерозойских метаморфических образований. В поверхностных отложениях формируются геохимические ореолы и потоки рассеяния $\mathrm{Cu}, \mathrm{Zn}, \mathrm{S}, \mathrm{Au}, \mathrm{Ag}$ и $\mathrm{Co}$, связанные с их месторождениями. Определение коэффициентов региональной концентрации (Крк) относительно среднего содержания элементов в почвообразующих комплексах Северного Кавказа позволяет выявить ассоциации химических элементов с выше- и нижефоновыми значениями (табл.1).

В протерозойских кристаллических сланцах и гнейсах преобладает тенденция превышения содержания большинства химических элементов над региональным литогеохимическим фоном, о чем свидетельствует среднее значение коэффициента региональной концентрации для 25 химических элементов, равное 1,24 . Нижефоновое содержание имеют такие химические элементы, как $\mathrm{Ba}, \mathrm{Mn}, \mathrm{Pb}$ и $\mathrm{Sr}$.

В палеозойских гранитоидах характерным является почти одинаковое количество химических элементов с выше- и нижефоновыми концентрациями относительно регионального фона. Среднее значение коэффициента региональной концентрации по 25 химическим элементам составляет 1,02 .

Для вулканогенно-терригенных отложений палеозоя типично повышенное содержание химических элементов группы железа в связи с наличием в составе основных пород [3]. Относительно литогеохимического фона Северного Кавказа микроэлементный состав данного комплекса отложений характеризуется преобладанием вышефоновых содержаний химических элементов. Среднее значение коэффициента региональной концентрации для 25 химических элементов составляет 1,17 . Интенсивнее накапливаются такие химические элементы, как $\mathrm{Ag}, \mathrm{Nb}, \mathrm{Cu}, \mathrm{W}, \mathrm{Co}, \mathrm{Yb}, \mathrm{Y}, \mathrm{Sc}, \mathrm{Cr}, \mathrm{Ni}$ и V. В дефиците к региональному фону находятся $\mathrm{Pb}, \mathrm{Mn}, \mathrm{Zn}, \mathrm{Ba}, \mathrm{Be}$ и $\mathrm{Sr}$.

Почвообразующий комплекс терригенных отложений верхнего палеозоя образован пестрыми кварцевыми песчаниками, алевролитами, глинистыми сланцами [17]. В микроэлементном составе отложений преобладают ассоциации химических элементов, накапливающихся относительно регионального литогеохимического фона, о чем свидетельствует среднее значение коэффициента региональной концентрации по 25 химическим элементам 1,14. В дефиците по отношению к региональному фону $\mathrm{Zn}, \mathrm{Ba}, \mathrm{Mn}, \mathrm{Be}$ и $\mathrm{Sr}$.

Литогеохимическое поле терригенно-карбонатных отложений триаса располагается в районе северо-западного погружения Передового хребта в верхнем течении рек Лабы и Белой. Геохимическими особенностями данных отложений, как отмечает В.В. Дьяченко [3], является превышение ими кларков карбонатных пород по большинству химических элементов, что обусловлено существенной примесью терригенного материала (в основном глин и 
Таблица 1.

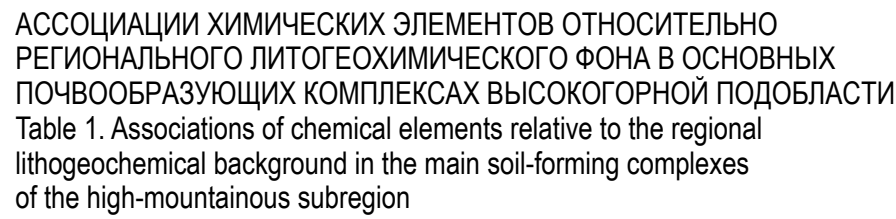

\begin{tabular}{|c|c|c|}
\hline $\begin{array}{l}\text { Почво-образующие } \\
\text { комплексы / Soil- } \\
\text { forming complexes }\end{array}$ & $\begin{array}{l}\text { С вышефоновым содержанием } \\
\text { (Крк >1,0)/ With above-mentioned content } \\
(\text { Крк >1,0) }\end{array}$ & $\begin{array}{l}\text { С нижефоновым содержа- } \\
\text { нием }(\text { Крк }<1,0) / \text { With below- } \\
\text { background content }(\text { Крк > 1,0) }\end{array}$ \\
\hline $\begin{array}{l}\text { Протерозойские } \\
\text { кристаллические } \\
\text { сланцы и гнейсы / } \\
\text { Proterozoic crystalline } \\
\text { schists and gneisses }\end{array}$ & $\begin{array}{l}\mathrm{Mo}_{1,92>} \mathrm{Y}_{1,61>} \mathrm{Yb}_{1,55} \mathrm{~W}_{1,54>} \mathrm{Cu}_{1,50>} \\
\mathrm{V}_{1,43>} \mathrm{Ni}_{1,42>} \mathrm{Sn}_{1,41>} \mathrm{Zr}_{1,39>} \mathrm{Ga}_{1,38>} \\
\mathrm{Co}_{1,34>} \mathrm{Cr}_{1,24>} \mathrm{Ag}_{1,21>} \mathrm{Li}_{1,18>} \mathrm{Ti}_{1,18>} \mathrm{Be}_{1,02} \\
\mathrm{Nb}_{1,10>} \mathrm{Zn}_{1,0>} \mathrm{Sc}_{1,09>}>\mathrm{Ge}_{1,09>} \mathrm{P}_{1,08>} \mathrm{Be}_{1,02}\end{array}$ & $\mathrm{Ba}_{0,93>} \mathrm{Mn}_{0,87>} \mathrm{Pb}_{0,83>} \mathrm{Sr}_{0,49}$ \\
\hline $\begin{array}{l}\text { Палеозойские } \\
\text { гранитоиды / } \\
\text { Paleozoic granitoids }\end{array}$ & $\begin{array}{l}\mathrm{Ga}_{1,54>} \mathrm{Sn}_{1,51>} \mathrm{Be}_{1,36>} \mathrm{P}_{1,34>} \mathrm{Pb}_{1,28} \mathrm{Nb}_{1,27>} \\
\mathrm{Ag}_{1,14>} \mathrm{Yb}_{1,12>} \mathrm{Ge}_{1,09>}>\mathrm{Ti}_{1,08>}>\mathrm{Y}_{1,08>} \mathrm{Ba}_{1,06} \\
\mathrm{Mo}_{1,00}\end{array}$ & $\begin{array}{l}\mathrm{V}_{0,97>} \mathrm{Li}_{0,96>} \mathrm{Sc}_{0,95>} \mathrm{W}_{0,94>} \\
\mathrm{Cr}_{0,93>}>\mathrm{Zn}_{0,90>} \mathrm{Cu}_{0,87>} \mathrm{Zr}_{0,79>} \mathrm{Co}_{0,72>} \\
\mathrm{Mn}_{0,57>} \mathrm{Sr}_{0,54>} \mathrm{Ni}_{0,53}\end{array}$ \\
\hline $\begin{array}{l}\text { Tерригенно-вулка- } \\
\text { ногенные палеозоя / } \\
\text { Terrigenous- } \\
\text { volcanogenic } \\
\text { Paleozoic }\end{array}$ & $\begin{array}{l}\mathrm{Ag}_{1,67>} \mathrm{Nb}_{1,61>} \mathrm{Cu}_{1,58} \mathrm{~W}_{1,43>} \mathrm{Co}_{1,43>} \mathrm{Yb}_{1,43>} \mathrm{Y}_{1,39>}> \\
\mathrm{Cr}_{1,32>}>\mathrm{Ni}_{1,31>} \mathrm{V}_{1,28>} \mathrm{Mo}_{1,16>}>\mathrm{Sn}_{1,3>} \\
\mathrm{Li}_{1,14>} \mathrm{Zr}_{1,13>} \mathrm{Ga}_{1,13>} \mathrm{Ge}_{1,09}> \\
\mathrm{Ti}_{1,02}\end{array}$ & $\begin{array}{l}\mathrm{Pb}_{0,95>} \mathrm{Mn}_{0,91>} \mathrm{Zn}_{0,90>} \mathrm{Ba}_{0,85>}>\mathrm{Be}_{0,76>} \\
\mathrm{Sr}_{0,47}\end{array}$ \\
\hline $\begin{array}{l}\text { Терригенные } \\
\text { палеозоя / } \\
\text { Terrigenous } \\
\text { Paleozoic }\end{array}$ & $\begin{array}{l}\mathrm{Cr}_{1,66>} \mathrm{Ni}_{1,59>} \mathrm{Nb}_{1,49>} \mathrm{Mo}_{1,28>} \mathrm{Y}_{1,28>}>\mathrm{Zr}_{1,27>} \\
\mathrm{V}_{1,27>} \mathrm{Cu}_{1,24>} \mathrm{Ga}_{1,20>} \mathrm{Sc}_{1,20>} \mathrm{Li}_{1,17>}>\mathrm{W}_{1,16>} \\
\mathrm{Sn}_{1,15>} \mathrm{Co}_{1,15>} \mathrm{Ge}_{1,09>} \mathrm{P}_{1,08>} \mathrm{Yb}_{1,05>} \mathrm{Ti}_{1,05>} \\
\mathrm{Pb}_{1,05>} \mathrm{Ag}_{1,04}\end{array}$ & $\begin{array}{l}\mathrm{Zn}_{0,91>} \mathrm{Ba}_{0,91>} \mathrm{Mn}_{0,89>} \\
\mathrm{Be}_{0,83>} \mathrm{Sr}_{0,51}\end{array}$ \\
\hline $\begin{array}{l}\text { Терригенно- } \\
\text { карбонатные } \\
\text { триаса / Terrigenous- } \\
\text { carbonate Triassic }\end{array}$ & $\mathrm{Sr}_{2,88>} \mathrm{Ba}_{1,41>} \mathrm{Mn}_{1,38>} \mathrm{Ni}_{1,05}$ & $\begin{array}{l}\mathrm{Ag}_{0,98>} \mathrm{W}_{0,88>} \mathrm{Sn}_{0,84>} \mathrm{Li}_{0,81>} \\
\mathrm{Sc}^{0,78>} \mathrm{Zn}_{0,77>} \mathrm{Ti}_{0,75>} \mathrm{Ge}_{0,75>} \\
\mathrm{Co}_{0,67>} \mathrm{Pb}_{0,67>} \mathrm{Cu}_{0,66>} \mathrm{Y}_{0,59>} \\
\mathrm{Ga}_{0,56>} \mathrm{Yb}_{0,56>} \mathrm{P}_{0,56>} \mathrm{Zr}_{0,50>} \\
\mathrm{Cr}_{0,50>} \mathrm{Nb}_{0,45>} \mathrm{Be}_{0,42>} \mathrm{V}_{0,34>} \\
\mathrm{Mo}_{0,32}\end{array}$ \\
\hline
\end{tabular}

алевритов), характеризующегося более высокими кларками. Отличительной особенностью микроэлементного состава терригенно-карбонатных отложений триаса являются нижефоновые концентрации подавляющего большинства химических элементов. Это показывается средним значением коэффициента региональной концентрации, который меньше 1,0 и составляет 0,80 . Тенденция накопления относительно регионального литогеохимического фона в терригенно-карбонатных отложениях триаса характерна только для четырех химических элементов: $\mathrm{Sr}, \mathrm{Ba}, \mathrm{Mn}$ и Ni. 
Североюрско-Дагестанская высокогорно-среднегорная физико-географическая подобласть объединяет структурные элементы нижне- и среднеюрских отложений, образовавшихся в ранние стадии альпийского (киммерийского) цикла геологического развития Кавказа. Выделяются региональные литогеохимические поля терригенно-вулканогенных и терригенных комплексов юрских отложений.

Метаморфизованные терригенно-вулканогенные отложения юры приурочены к Гойтскому антиклинорию в Западном Кавказе и антиклинориям Главного и Бокового хребтов Дагестана. Выраженный рельеф высоко- и средневысотных структурно-денудационных гор позволяет рассматривать почвообразующий комплекс данных пород как верхние слои автоморфной остаточной коры выветривания. В микроэлементном составе терригенно-вулканогенных отложений юры преобладают вышефоновые содержания химических элементов (табл. 2). Почвообразующий комплекс терригенных юрских отложений приурочен к Северо-Юрской депрессии. Нижне- и среднеюрские терригенные отложения представлены различными песчаниками, алевролитами, аргиллитами, песчано-глинистыми аспидными сланцами. Геоморфологические условия их распространения позволяют рассматривать поверхностные слои пород в качестве переотложенной коры выветривания, в долинах рек гидроморфной переотложенной. В составе отложений преобладает ассоциация химических элементов с вышефоновым содержанием относительно литогеохимического фона. Тенденция сильного накопления характерна для Zn, $\mathrm{Nb}, \mathrm{V}, \mathrm{Pb}, \mathrm{Co}, \mathrm{Cr}, \mathrm{Ni}, \mathrm{Ti}, \mathrm{Ga}, \mathrm{P}, \mathrm{Yb}$ и Ge. Среднее значение коэффициента региональной концентрации для 25 химических элементов составляет 1,17. Ассоциацию микроэлементов с содержаниями, ниже регионального литогеохимического фона, составляют $\mathrm{Be}, \mathrm{Ag}, \mathrm{Ba}, \mathrm{Mn}, \mathrm{Mo}$ и $\mathrm{Sr}$.

Кубано-Дагестанская физико-географическая подобласть среднегорий включает моноклинальные и сложноскладчатые структуры верхнеюрских и меловых отложений Большого склона Большого Кавказа и северо-западной его части. Почвообразующий комплекс терригенно-карбонатных отложений юры-мела и мела-палеогена приурочен к куэстовым хребтам и может рассматриваться в качестве элемента автоморфной остаточной коры выветривания. Почвообразующий комплекс терригенных меловых отложений занимает межкуэстовую депрессию между Скалистым и Пастбищным хребтом и представляет собой верхние слои переотложенной коры выветривания, в долинах рек - гидроморфной переотложенной.

Терригенно-карбонатные отложения верхней юры и мела относятся к морфоструктурному комплексу Скалистого хребта. Определение коэффициентов региональной концентрации химических элементов в терригенно-карбонатных отложениях юры и мела показывает их значительное обеднение по сравнению с региональным литогеохимическим фоном (табл. 3). 
Таблица 2.

$$
\begin{aligned}
& \text { АССОЦИАЦИИ ХИМИЧЕСКИХ ЭЛЕМЕНТОВ ОТНОСИТЕЛЬНО } \\
& \text { РЕГИОНАЛЬНОГО ЛИТОГЕОХИМИЧЕСКОГО ФОНА В ОСНОВНЫХ } \\
& \text { ПОЧВООБРАЗУЮЩИХ КОМПЛЕКСАХ ВЫСОКОГОРНО-СРЕДНЕГОРНОЙ } \\
& \text { ПОДОБЛАСТИ } \\
& \text { Table 2. Association of chemical elements in relation to the regional } \\
& \text { lithogeochemical background in the main soil-forming complexes } \\
& \text { of the high-middle-mountainous subregion }
\end{aligned}
$$

\begin{tabular}{|c|c|c|}
\hline $\begin{array}{l}\text { Почво-образующие } \\
\text { комплексы / } \\
\text { Soil-forming complexes }\end{array}$ & $\begin{array}{l}\text { С вышефоновым содержанием } \\
\text { (Крк > 1,0)/ With above-mentioned content } \\
(\text { Крк > 1,0) }\end{array}$ & $\begin{array}{l}\text { С нижефоновым содержанием } \\
\text { (Крк }<1,0) / \text { With below-background } \\
\text { content }(\text { Крк > 1,0) }\end{array}$ \\
\hline $\begin{array}{l}\text { Терригенно- } \\
\text { вулканогенные юры / } \\
\text { Terrigenous- } \\
\text { volcanogenic Jurassic }\end{array}$ & $\begin{array}{l}\mathrm{Zn}_{1,38>} \mathrm{Ti}_{1,37>} \mathrm{V}_{1,34>} \mathrm{P}_{1,34>} \mathrm{Ga}_{1,3>} \mathrm{Nb}_{1,31>} \\
\mathrm{Ge}_{1,22>} \mathrm{Ni}_{1,28>} \mathrm{Co}_{1,23>} \mathrm{Yb}_{1,18>} \mathrm{Sn}_{1,17>} \mathrm{Cr}_{1,16>} \\
\mathrm{Pb}_{1,15>} \mathrm{Be}_{1,13>} \mathrm{W}_{1,10>}>\mathrm{Li}_{1,05>} \mathrm{Y}_{1,04}\end{array}$ & $\begin{array}{l}\mathrm{Mn}_{0,98>} \mathrm{Sc}_{0,95>}>\mathrm{Zr}_{0,92>} \mathrm{Cu}_{0,89>} \mathrm{Ag}_{0,88>} \\
\mathrm{Ba}_{0,87>} \mathrm{Mo}_{0,80>} \mathrm{Sr}_{0,61}\end{array}$ \\
\hline $\begin{array}{l}\text { Терригенные юры / } \\
\text { Terrigenous Jurassic }\end{array}$ & $\begin{array}{l}\mathrm{Zn}_{1,67>} \mathrm{Nb}_{1,37>} \mathrm{V}_{1,35>} \mathrm{Pb}_{1,34>} \mathrm{Co}_{1,34>} \mathrm{Cr}_{1,30>} \\
\mathrm{Ni}_{1,29>} \mathrm{Ti}_{1,26>} \mathrm{Ga}_{1,26>} \mathrm{P}_{1,25>} \mathrm{Yb}_{1,24>} \mathrm{Ge}_{1,23>} \\
\mathrm{Sc}_{1,16>} \mathrm{W}_{1,16>} \mathrm{Zr}_{1,15>}>\mathrm{Sn}_{1,15>}>\mathrm{Li}_{1,14>} \mathrm{Y}_{1,13>} \\
\mathrm{Cu}_{1,12}\end{array}$ & $\begin{array}{l}\mathrm{Be}_{0,98>} \mathrm{Ag}_{0,96>} \mathrm{Ba}_{0,95>} \mathrm{Mn}_{0,94>} \\
\mathrm{Mo}_{0,92>}>\mathrm{Sr}_{0,59}\end{array}$ \\
\hline
\end{tabular}

\begin{tabular}{|c|c|c|}
\hline $\begin{array}{l}\text { Почво-образующие } \\
\text { комплексы / Soil- } \\
\text { forming complexes }\end{array}$ & $\begin{array}{l}\text { С вышефоновым содержанием } \\
\text { (Крк > 1,0) / With above-mentio- } \\
\text { ned content (Крк > 1,0) }\end{array}$ & $\begin{array}{l}\text { С нижефоновым содержанием }(\text { Крк < 1,0) I } \\
\text { With below-background content }(\text { Крк >1,0) }\end{array}$ \\
\hline $\begin{array}{l}\text { Терригенно- } \\
\text { карбонатные юры } \\
\text { и мела / } \\
\text { Terrigenous- } \\
\text { carbonate } \\
\text { jura and mel }\end{array}$ & - & $\begin{array}{l}\mathrm{Mn}_{0,98>} \mathrm{Be}_{0,95>} \mathrm{Sr}_{0,93>} \mathrm{Y}_{0,86>} \mathrm{Zr}_{0,77>} \mathrm{Ba}_{0,74>} \\
\mathrm{Sc}_{0,69>} \mathrm{Pb}_{0,67} \mathrm{Ag}_{0,65>} \mathrm{MO}_{0,64>} \mathrm{Yb}_{0,62>} \mathrm{Li}_{0,61>} \\
\mathrm{W}_{0,61>} \mathrm{Ti}_{0,57>} \mathrm{Nb}_{0,55>} \mathrm{Ge}_{0,54>} \mathrm{P}_{0,54>} \mathrm{Sn}_{0,48>} \mathrm{Ni}_{0,45>} \\
\mathrm{Co}_{0,44>} \mathrm{Cu}_{0,43>} \mathrm{Zn}_{0,40>}>\mathrm{V}_{0,37>} \mathrm{Ga}_{0,32>} \mathrm{Cr}_{0,29}\end{array}$ \\
\hline $\begin{array}{l}\text { Терригенно- } \\
\text { карбонатные мела } \\
\text { и палеогена / } \\
\text { Terrigenous- } \\
\text { carbonate mel } \\
\text { and Paleogene }\end{array}$ & $\mathrm{Sr}_{1,69>} \mathrm{Mn}_{1,32>} \mathrm{Be}_{1,02}$ & $\begin{array}{l}\mathrm{Ba}_{0,93>} \mathrm{Y}_{0,92>} \mathrm{Zr}_{0,85>} \mathrm{Ag}_{0,77>} \mathrm{Sc}_{0,73>} \mathrm{Mo}_{0,72>} \\
\mathrm{W}_{0,72>}>\mathrm{Ti}_{0,70>} \mathrm{Cu}_{0,69>} \mathrm{Li}_{0,65>} \mathrm{Pb}_{0,63>} \mathrm{P}_{0,63>} \mathrm{Yb}_{0,62>} \mathrm{Ge}_{0} \\
{ }^{61>} \mathrm{Cr}_{0,60>} \mathrm{V}_{0,59>} \mathrm{Sn}_{0,57>} \mathrm{Co}_{0,56>} \mathrm{Nb}_{0,53>} \\
\mathrm{Zn}_{0,48>} \mathrm{Ni}_{0,45>} \mathrm{Ga}_{0,39}\end{array}$ \\
\hline $\begin{array}{l}\text { Tерригенные мела / } \\
\text { Terrigenous mel }\end{array}$ & $\begin{array}{l}\mathrm{Zr}_{1,55>} \mathrm{Co}_{1,35>} \mathrm{Zn}_{1,30>} \mathrm{Y}_{1,30>} \mathrm{Nb}_{1,30>} \mathrm{Ti}_{1,2} \\
\mathrm{~V}_{1,29>} \mathrm{Ga}_{1,28>} \mathrm{Gb}_{1,28>} \mathrm{Pi}_{1,24>} \mathrm{Ni}_{1,1>}>\mathrm{Ni}_{1,19>} \mathrm{S} \\
\mathrm{Cu}_{1,16>} \mathrm{Be}_{1,13>} \mathrm{P}_{1,13>} \mathrm{Ba}_{1,11>} \mathrm{Ag}_{1,11>} \mathrm{Ge} \\
\mathrm{Sn}_{1,08>} \mathrm{Mn}_{1,06>} \mathrm{Pb}_{1,01}\end{array}$ & $\mathrm{~W}_{0,83>} \mathrm{Sr}_{0,81>} \mathrm{Mo}_{0,80}$ \\
\hline
\end{tabular}

Таблица 3.

АССОЦИАЦИИ ХИМИЧЕСКИХ ЭЛЕМЕНТОВ ОТНОСИТЕЛЬНО РЕГИОНАЛЬНОГО ЛИТОГЕОХИМИЧЕСКОГО ФОНА В ОСНОВНЫХ ПОЧВООБРАЗУЮЩИХ КОМПЛЕКСАХ СРЕДНЕГОРНОЙ ПОДОБЛАСТИ Table 3. Association of chemical elements in relation to the regional lithogeochemical background in the main soil-forming complexes of the mid-range subregion

Литогеохимическое поле терригенно-карбонатных отложений мела и палеогена располагается в пределах Пастбищного, Дарьинского, Боргустанского и Джинальского хребтов. По сравнению с региональным литогеохимическим фоном почвообразующих пород Северного Кавказа в терригенно-карбонатных отложениях мела и палеогена происходит обеднение большинс- 
твом химических элементов. Среднее значение коэффициента региональной концентрации для 25 химических элементов составляет 0,74. Вышефоновые уровни характерны для трех элементов ( $\mathrm{Sr}, \mathrm{Mn}$ и $\mathrm{Be}$ ), а нижефоновые - у всех остальных химических элементов.

В терригенных меловых отложениях большинство микроэлементов имеют превышение содержаний над региональным литогеохимическим фоном. Среднее значение коэффициента региональной концентрации для 25 химических элементов составляет 1,16. Ряд сильного накопления (Крк > 1,2) образуют $\mathrm{Zr}, \mathrm{Co}, \mathrm{Zn}, \mathrm{Y}, \mathrm{Nb}, \mathrm{Ti}, \mathrm{Cr}, \mathrm{V}, \mathrm{Ga}$ и $\mathrm{Yb}$.

\section{Черноморско-Терско-Сунженская физико-географическая} подобласть низкогорий и предгорных равнин характеризуется развитием литогеохимических полей, связанных с палеогеновыми и неогеновыми отложениями. Почвообразующие комплексы терригенных отложений палеогена и неогена приурочены к межкуэстовой депрессии между Лесистым и Пастбищным хребтами и по условиям залегания в рельефе являются верхними слоями переотложенной коры выветривания, в долинах рек гидроморфной переотложенной. Относительно регионального фона почвообразующих пород Северного Кавказа в данных отложениях преобладает обогащение химическими элементами (табл.4). Среднее значение коэффициента региональной концентрации по 25 химическим элементам составляет 1,17.

Литогеохимическое поле терригенно-карбонатных неогеновых отложений приурочено к низкогорьям, включающим останцы неогеновой куэсты и систему низких горных гряд Лесистого хребта. По геоморфологическим особенностям залегания поверхностные отложения относятся к верхним слоям автоморфной остаточной коры выветривания. Микроэлементный состав отложений отличается преобладанием ассоциации химических элементов с нижефоновыми содержаниями. Среднее значение коэффициента региональной концентрации для 25 химических элементов составляет 0,78 .

Предгорные наклонные аллювиальные равнины Черноморско-ТерскоСунженской физико-географической подобласти сложены аллювиальными и флювиогляциальными отложениями, прикрытыми сверху лёссовидными суглинками. К более высоким эрозионно-аккумулятивным террасам предгорных наклонных равнин, имеющим верхнеплиоценовый возраст, приурочено литогеохимическое поле терригенных отложений неогена. В микроэлементном составе отложений преобладает ассоциация химических элементов, имеющих концентрации выше регионального фона с незначительным обогащением. Это показывает и среднее значение коэффициента региональной концентрации для 25 химических элементов, равное 1,06 .

К более низким аккумулятивным террасовым уровням наклонных равнин, являющихся по возрасту четвертичными, приурочено литогеохимическое поле аллювиальных четвертичных отложений. Относительно регио- 
Таблица 4.

$$
\begin{aligned}
& \text { АССОЦИАЦИИ ХИМИЧЕСКИХ ЭЛЕМЕНТОВ ОТНОСИТЕЛЬНО } \\
& \text { РЕГИОНАЛЬНОГО ЛИТОГЕОХИМИЧЕСКОГО ФОНА В ОСНОВНЫХ } \\
& \text { ПОЧВООБРАЗУЮЩИХ КОМПЛЕКСАХ ПОДОБЛАСТИ НИЗКОГОРИЙ } \\
& \text { И ПРЕДГОРНЫХ РАВНИН } \\
& \text { Table } 4 \text {. Associations of chemical elements in relation to the regional } \\
& \text { lithogeochemical background in the main soil-forming complexes } \\
& \text { of the subregion of lowlands and foothill plains }
\end{aligned}
$$

\begin{tabular}{|c|c|c|}
\hline $\begin{array}{l}\text { Почво-образующие } \\
\text { комплексы / } \\
\text { Soil-forming complexes }\end{array}$ & $\begin{array}{l}\text { С вышефоновым содержанием } \\
\text { (Крк }>1,0) / \text { With above-mentioned } \\
\text { content }(\text { Крк }>1,0)\end{array}$ & $\begin{array}{l}\text { С нижефоновым содержанием } \\
\text { (Крк }<1,0) / \text { With below-background } \\
\text { content }(\text { Крк > 1,0) }\end{array}$ \\
\hline $\begin{array}{l}\text { Терригенные } \\
\text { палеогена и неогена / } \\
\text { Terrigenous Paleogene } \\
\text { and Neogene }\end{array}$ & $\begin{array}{l}\mathrm{Mo}_{1,84>} \mathrm{Zn}_{1,53>}>\mathrm{V}_{1,44>} \mathrm{Cr}_{1,32>} \mathrm{Ge}_{1,29>} \\
\mathrm{Pb}_{1,27>} \mathrm{Ga}_{1,23}>\mathrm{Cu}_{1,23}>\mathrm{Nb}_{1,21>} \mathrm{Sn}_{1,20>} \\
\mathrm{Co}_{1,18>} \mathrm{Ni}_{1,18>} \mathrm{Li}_{1,17>} \mathrm{P}_{1,17>} \mathrm{Ti}_{1,1,7>} \mathrm{Zr}_{1,14>} \\
\mathrm{Yb}_{1,12>} \mathrm{Ba}_{1,10>} \mathrm{Sc}_{1,08>} \mathrm{Be}_{1,06>} \mathrm{W}_{1,05} \mathrm{Ag}_{1,04}\end{array}$ & $\mathrm{Y}_{0,93>} \mathrm{Sr}_{0,81>} \mathrm{Mn}_{0,58}$ \\
\hline $\begin{array}{l}\text { Терригенно-карбо- } \\
\text { натные неогена / } \\
\text { Terrigenous-carbonate } \\
\text { Neogene }\end{array}$ & $\mathrm{Sr}_{1,10>} \mathrm{Ba}_{1,00}$ & $\begin{array}{l}\mathrm{Mn}_{0,97>}>\mathrm{Be}_{0,95>} \mathrm{Y}_{0,88>} \mathrm{W}_{0,88>} \mathrm{Mo}_{0,88>} \mathrm{Zr}_{0,88>} \\
\mathrm{Co}_{0,87>} \mathrm{Pb}_{0,82>}>\mathrm{Nb}_{0,79>} \mathrm{Ti}_{0,79>} \mathrm{Sc}_{0,78>} \mathrm{Li}_{0,77>} \\
\mathrm{Ge}^{0,75>} \mathrm{Ag}_{0,74>} \mathrm{Yb}_{0,74>}>\mathrm{P}_{0,73>} \mathrm{Zn}_{0,69>} \mathrm{Ga}_{0,63>} \\
\mathrm{Cu}_{0,62>} \mathrm{Cr}_{0,61>} \mathrm{Ni}_{0,61>} \mathrm{Sn}_{0,57>} \mathrm{V}_{0,55}\end{array}$ \\
\hline $\begin{array}{l}\text { Терригенные } \\
\text { неогена / Terrigenous } \\
\text { Neogene }\end{array}$ & $\begin{array}{l}\mathrm{Mn}_{1,36>} \mathrm{Zn}_{1,18>} \mathrm{Cr}_{1,16} \mathrm{Ba}_{1,15>} \mathrm{Pb}_{1,14>} \\
\mathrm{Cu}_{1,14>} \mathrm{Be}_{1,13} \mathrm{~V}_{1,13}>\mathrm{Yb}_{1,12>}>\mathrm{Ni}_{1,11>} \\
\mathrm{Ge}_{1,09>} \mathrm{Y}_{1,16>>} \mathrm{Ti}_{1,06>} \mathrm{Sc}_{1,06>} \mathrm{Nb}_{1,04>} \\
\mathrm{Sn}_{1,03>} \mathrm{Li}_{1,02>} \mathrm{Zr}_{1,02>} \mathrm{Ga}_{1,00}\end{array}$ & $\mathrm{~W}_{0,99>} \mathrm{Ag}_{0,94>} \mathrm{Sr}_{0,94>} \mathrm{P}_{0,92>} \mathrm{Co}_{0,92>} \mathrm{Mo}_{0,80}$ \\
\hline $\begin{array}{l}\text { Аллювиальные / } \\
\text { Alluvial }\end{array}$ & $\begin{array}{l}\mathrm{Sc}_{1.93} \mathrm{Zn}_{1.71>} \mathrm{Mn}_{1.55>} \mathrm{Ba}_{1.54>} \mathrm{Co}_{1.49>} \\
\mathrm{Ni}_{1.46>}>\mathrm{Cr}_{1.43>}>\mathrm{Pb}_{1.43>} \mathrm{V}_{1,42>} \mathrm{Cu}_{1,39>} \mathrm{W}_{1,38>} \mathrm{Ge}_{1.36} \\
\mathrm{Ti}_{1.36>} \mathrm{Sr}_{1.26>}>\mathrm{P}_{1.25>} \mathrm{Li}_{1,25>} \mathrm{Ag}_{1,19>}>\mathrm{Be}_{1,05} \\
\mathrm{Yb}_{1.18>} \mathrm{Zr}_{1,17>} \mathrm{Ga}_{1,10>} \mathrm{Y}_{1,09>} \mathrm{Sn}_{1,05>} \mathrm{Be}_{1,02}\end{array}$ & $\mathrm{Mo}_{0,92>} \mathrm{Nb}_{0,75}$ \\
\hline
\end{tabular}

нального литогеохимического фона Северного Кавказа аллювиальные четвертичные отложения являются самыми обогащенными. Среднее значение коэффициента региональной концентрации для 25 химических элементов наибольшее среди всех почвообразующих комплексов - 1,31. Как отмечает В.В. Добровольский [5], аллювиальные отложения относятся к переотложенной коре выветривания, имеют транзитный характер формирования, испытали длительное перемещение и разбавлены компонентами невыветренных пород. Их геохимические особенности для Большого Кавказа обуславливаются поступающим из высокогорных и среднегорных областей обломочным материалом устойчивых к выветриванию магматических и метаморфических пород. Сравнительно небольшая длительность гипергенного преобразования аллювиальных отложений в связи с их относительной молодостью формирования, их переотложенный характер также обуславливает наличие в их составе устойчивых компонентов и высокие концентрации многих химических элементов. Для данных отложений характерно значительное превышение литогеохимического фона у большой группы химических элементов. Ниже регионального фона находится содержание только двух химических элементов - Мо и $\mathrm{Nb}$. 


\section{Выводы}

Для современных физико-географических подобластей Большого Кавказа разных высотных уровней ландшафтной дифференциации (высокогорной, высокогорно-среднегорной, среднегорной и низкогорной с предгорными равнинами) характерны свои литогеохимические поля поверхностных почвообразующих отложений разного генезиса, времени формирования, литологии. Геохимическая специфика почвообразующих комплексов во многом обусловлена сложным характером процессов гипергенного преобразования пород, перераспределения продуктов выветривания в многообразных ландшафтно-геохимических условиях, менявшихся в ходе эволюционно развития ландшафтов Северного Кавказа.

В литогеохимических полях почвообразующих отложений ЭльбрусКазбековской высокогорной и Североюрско-Дагестанской высокогорно-среднегорной физико-географических подобластей преобладают химические элементы, концентрации которых превышают региональный литогеохимический фон. Вышефоновые ассоциации химических элементов характерны для поверхностных отложений автоморфной остаточной коры выветривания и терригенных отложений переотложенной коры выветривания. Несмотря на то, что эти литогеохимические поля наиболее длительное время подвергались интенсивным процессам выветривания и выноса материала в орогенный этап развития ландшафтов Большого Кавказа, их геохимические особенности в значительной степени определяются большой долей устойчивых к выветриванию минералов магматических и метаморфических пород. В имеющих другой генезис терригенно-карбонатных отложениях триаса преобладают нижефоновые ассоциации химических элементов.

В геохимической дифференциации литогенной основы Кубано-Дагестанской среднегорной и Черноморско-Терско-Сунженской низкогорной с предгорными равнинами физико-географических подобластей прослеживается определенная связь с элементами рельефа. Для литогеохимических полей положительных форм рельефа (куэстовых хребтов) с поверхностными терригенно-карбонатными отложениями автоморфной остаточной коры выветривания характерно преобладание нижефоновых ассоциаций химических элементов. Межкуэстовым депрессиям и наклонным равнинам, занятым и сформированным продуктами переотложенной коры выветривания, соответствуют обогащенные относительно регионального фона литогеохимические поля терригенных и аллювиальных отложений с преобладанием вышефоновых ассоциаций химических элементов. 


\section{БИБЛИОГРАФИЧЕСКИЙ СПИСОК}

1. Мильков Ф.Н. Физическая география: учение о ландшафте и географическая зональность. Воронеж: Изд-во ВГУ, 1986. 328 c. URL: http:// http://www.geoversum.by/catalog/item5746. (дата обращения 29.07.2018).

2. Добровольский В.В. Гипергенез и коры выветривания / Избранные труды. Т. 1. М.: Научный мир. 2007. 512 c. URL: http://www. pochva.com. (дата обращения 27.07.2018).

3. Дьяченко В.В. Геохимия, систематика и оценка состояния ландшафтов Северного Кавказа. Ростов-на-Дону: Комплекс. 2004. 268 c. URL: https://elibrary.ru (дата обращения 15.02.2018).

4. Дьяченко В.В., Матасова И.Ю. Региональные кларки химических элементов в почвах европейской части юга России // Почвоведение. 2016. № 10. C.1159-1166. DOI: 10.7868/ S0032180X16100063.

5. Дегтярева Т.В., Шальнев В.А., Лысенко А.В. Геохимические поля горных пород и почв Большого Кавказа: эволюционный подход и методы исследования // Устойчивое развитие горных территорий. 2017. Т. 9. №3 (33). С. 219-232. DOI: 10.21177/19984502-2017-9-3-219-232.

6. Шальнев В.А. Эволюция ландшафтов Северного Кавказа. Ставрополь: СГУ. 2007. 309 c. URL: https://elibrary.ru (дата обращения 27.05.2018).

7. Сафронов И.Н. Геоморфология Северного Кавказа. Ростовна-Дону: Издательство Ростовского университета, 1969. 217 с. URL: http://www.pochva.com. (дата обращения 01.08.2018).

8. Ковда В.А. Основы учения о почвах. Общая теория почвообразовательного процесса. Книга вторая. М.: Наука. 1973. 467 с. URL: http://www.pochva.com. (дата обращения 07.07.2018).

9. Полынов Б.Б. Кора выветривания. Часть 1. Процессы выветривания. Основные фазы и формы выветривания и их распределение. Л.: Изд-во АН СССР, 1934. 242 c. URL: http://www.pochva. com. (дата обращения 05.07.2018).

10. Makhinova, A. F., Makhinov, A. N., Kuptsova, V. A., Yermoshin, V. V. Geochemical differentiation of soils in the amur basin (russian part). Journal of Geochemical Exploration, 2013. 132, 140-148. DOI:10.1016/j.gexplo.2013.06.011

11. Nesse, William D. Introduction to Mineralogy. New York: Oxford University Press, 2 edition. 2012. 496 p.

12. Scarciglia, F., Critelli, S., Borrelli, L., Coniglio, S., Muto, F., \&Perri, F. (2016). Weathering profiles in granitoid rocks of the sila massif uplands, calabria, southern italy: New insights into their formation processes and rates. SedimentaryGeology, 336, 46-67. DOI:10.1016/ j.sedgeo.2016.01.015.

13. Measurement, collaborative learning and research for sustainable use of ecosystem services: landscape concepts and europe as laboratory / P. Angelstam, M. Grodzynskyi, K. Andersson et al. // Ambio. 2013. Vol. 42, no. 2. P. 129-145. 
14. FAO (2015.): Mapping the vulnerability of mountain peoples to food insecurity. Rome.

15. Reimann, C., Fabian, K., Birke, M., Filzmoser, P., Demetriades, A., Négrel, P., de Caritat, P. (2017). GEMAS: Establishing geochemical background and threshold for 53 chemical elements in european agricultural soil. Applied Geochemistry, DOI:10.1016/j.apgeochem.2017.01.021

16. Roudposhti, G. M., Karbassi, A., \& Baghvand, A. (2016). A pollution index for agricultural soils. Archives of Agronomy and Soil Science, 62(10), 1411-1424. DOI: 10.1080/03650340.2016.1154542.

17. Черкасов М.И. Инженерно-геологическое районирование Северного Кавказа. Изд-во РГУ. 1985. URL: http://www.pochva.com. (дата обращения 22.07.2018).

\section{References}

1. Milkov F.N. Physical geography: the study of the landscape and geographical zoning. Voronezh: Izd. VGU, 1986. 328 p. URL: http:// http://www.geoversum.by/catalog/item5746. (accessed 29.07.2018).

2. Dobrovolsky V.V. Hypergenesis and weathering crust / Selected works. T.1. M.: The scientific world. 2007. 512 pp. URL: http://www. pochva.com. (accessed 27.07.2018).

3. Dyachenko V.V. Geochemistry and assessment of landscapes of the North Caucasus: dis. d-ra. geogr. nauk. Novorossiisk. 2004. 36 p. URL: https://elibrary.ru (accessed 15.02.2018).

4. Dyachenko V.V, Matasova I.Y. Regional'nye klarki himicheskih elementov v pochvah evropeiskoi chasti yuga Rossii // Pochvovedenie. 2016. № 10. C.1159-1166. DOI: 10.7868/S0032180X16100063.

5. Degtyareva TV, Shalnev VA, Lysenko A.V. Geochemical fields of rocks and soils of the Greater Caucasus: an evolutionary approach and methods of research // Sustainable development of mountain territories "- 2017. T. 9. № 3 (33). Pp. 219-232. DOI: 10.21177/19984502-2017-9-3-219-232.

6. Shalnev V.A. The evolution of the landscapes of the North Caucasus. Stavropol: SGU. 2007. URL: https://elibrary.ru (accessed 27.05.2018).

7. Safronov I.N. Geomorphology of the North Caucasus. Rostov-onDon: Publishing House of Rostov University, 1969. 217 p. URL: http://www.pochva.com. (accessed 01.08.2018).

8. Kovda V.A. Fundamentals of the doctrine of soils. General theory of the soil-forming process. The second book. M .: Science. 1973. 467 p. URL: http://www.pochva.com. (accessed 07.07.2018).

9. Polynov B.B. Weathering crust. Part 1. Processes of weathering. The main phases and forms of weathering and their distribution. L.: Publishing House of the Academy of Sciences of the USSR, 1934. 242 p. URL: http://www.pochva.com. (accessed 07.07.2018).

10. Makhinova, A. F., Makhinov, A. N., Kuptsova, V. A., Yermoshin, V. V. Geochemical differentiation of soils in the amur basin (russian 
part). Journal of Geochemical Exploration, 2013. 132, 140-148. DOI:10.1016/j.gexplo.2013.06.011

11. Nesse, William D. Introduction to Mineralogy. New York: Oxford University Press, 2 edition. 2012. 496 p.

12. Scarciglia, F., Critelli, S., Borrelli, L., Coniglio, S., Muto, F., \&Perri, F. (2016). Weathering profiles in granitoid rocks of the sila massif uplands, calabria, southern italy: New insights into their formation processes and rates. SedimentaryGeology, 336, 46-67. DOI:10.1016/ j.sedgeo.2016.01.015

13. Measurement, collaborative learning and research for sustainable use of ecosystem services: landscape concepts and europe as laboratory / P. Angelstam, M. Grodzynskyi, K. Andersson et al. // Ambio. 2013. Vol. 42, no. 2. - P. 129-145.

14. FAO (2015.): Mapping the vulnerability of mountain peoples to food insecurity. Rome.

15. Reimann, C., Fabian, K., Birke, M., Filzmoser, P., Demetriades, A., Négrel, P., de Caritat, P. (2017). GEMAS: Establishing geochemical background and threshold for 53 chemical elements in european agricultural soil. Applied Geochemistry, DOI:10.1016/j.apgeochem.2017.01.021

16. Roudposhti, G. M., Karbassi, A., \& Baghvand, A. (2016). A pollution index for agricultural soils. Archives of Agronomy and Soil Science, 62(10), 1411-1424. DOI: 10.1080/03650340.2016.1154542.

17. Cherkasov M.I. Engineering-geological zoning of the North Caucasus. RSU Publishing House. 1985. http://www.pochva.com. (accessed 22.07.2018).

Рукопись поступила в редакцию: 12.07.2018, принята к публикации 26.08.2018

\section{6 авторах}

Дегтярева Татьяна Васильевна, кандидат географических наук, доцент кафедры физической географии и кадастров ИМЕН СКФУ (Российская Федерация, 355009, СКФО, Ставропольский край, г. Ставрополь, ул. Пушкина, д. 1), Scopus ID: 57196119839, Researcher ID:, dtb.70@mail.ru, телефон: 89197318498.

Лиховид Андрей Александрович, доктор географических наук, кандидат биологических наук, профессор СКФУ, професссор кафедры экологии и природопользования ИМЕН СКФУ (Российская Федерация, 355009, СКФО, Ставропольский край, г. Ставрополь, ул. Пушкина, д. 1), Scopus ID: 57200209407, Researcher ID:, alikhovid@ ncfu.ru, телефон: (8652) 95-64-87.

Лиховид Наталья Геннадьевна, доктор биологических наук, профессор кафедры общей биологии и биоразнообразия СКФУ (Российская Федерация, 355009, СКФО, Ставропольский край, г. Ставрополь, ул. Пушкина, д. 3), Scopus ID:.., Researcher ID:, alikhovid@ncfu.ru, телефон: (8652) 33-08-55. 


\section{About the authors}

Degtyareva Tatyana Vasilyevna, candidate of geographical sciences, associate Professor of the Department of physical geography and cadastre SKFU. Phone: 89197318498. E-mail: dtb.70@mail.ru

Likhovid Andrey Aleksandrovich, Professor of the Department of Ecology and Nature Management of the Institute of Mathematics and Natural Sciences, Doctor of Geographical Sciences, Candidate of Biological Sciences, Professor of SKFU. Phone: (8652) 95-64-87; E-mail: alikhovid@ ncfu.ru

Likhovid Natalya Gennadievna, Doctor of Biological Sciences, Professor of the Department of General Biology and Biodiversity of SKFU (Russia, 355009, SKFO, Stavropol Territory, Stavropol, Pushkin St., 3), Scopus ID:.., Researcher ID :, alikhovid@ncfu.ru, phone: (8652) 33-08-55. 